\title{
Photoperiod Influence on the Cultivation of Steindachneridion scriptum (Pisces, Pimelodidae) Juvenile
}

\author{
Evoy Zaniboni-Filho*, David Reynalte-Tataje, Alex Pires de Oliveira Nuñer and Samira \\ Meurer \\ Laboratório de Biologia e Cultivo de Peixes de Água Doce; Universidade Federal de Santa Catarina; \\ Departamento de Aqüicultura; Rodovia SC 406, 3532; zaniboni@cca.ufsc.br; 88066-000; Florianópolis - SC - \\ Brazil
}

\begin{abstract}
This study aimed to evaluate the influence of photoperiod on juvenile suruvi (Steindachneridion scriptum) in six photoperiods: 24L-OD ( $L=$ Light; D= Dark), 18L-6D, 14L-10D, 10L-14D, 6L-18D and OL-24D. Juveniles measuring $176.8 \pm 13.2 \mathrm{~mm}$ and weighing $60.2 \pm 16.0 \mathrm{~g}$ were distributed in eighteen 150-L aquariums, stocked with 8 juveniles per aquarium. At the end of the study, treatments $24 \mathrm{~L}-0 \mathrm{D}(105.7 \pm 5.8 \mathrm{~g}$ and $845.9 \pm 46 \mathrm{~g})$ and $0 \mathrm{~L}-24 \mathrm{D}(93.3$ $\pm 4.9 \mathrm{~g}$ and $746.4 \pm 39.5 \mathrm{~g})$ were different $(P<0.05)$ on weight and biomass. Survival $(100 \pm 0.0 \%)$ and length $(212.5$ $\pm 2.5 \mathrm{~mm})$ were the same $(P>0.05)$ in all the treatments. The results showed that suruvi (Steindachneridion scriptum) reached better weight and biomass in extended light periods.
\end{abstract}

Key words: Steindachneridion scriptum, larviculture, photoperiod, growth

\section{INTRODUCTION}

The genus Steindachneridion presents a low number of species, and Steindachneridion scriptum (Miranda Ribeiro, 1918) is the only one inhabiting the area around Uruguay River. This fish species, which is spread all over the Neotropical region, can be found in Parana (Agostinho et al., 1997) and Uruguay (ZaniboniFilho and Schulz, 2003) river basins. It has carnivorous feeding habit and, like other Pimelodidae, prefers to inhabit deep areas.

Photoperiod is the most explicit natural sign to indicate the season (Gwinner, 1986) and, due to its stability and predictability, it can act as a cyclic change signpost before the changes actually occur (Brett, 1979). The synchronicity of the events and the activity regulation according to the different seasons can be crucial to many organisms, specially those inhabiting areas where the conditions of feeding, survival and reproduction vary throughout the year.

In fish culture, the importance of photoperiod has been confirmed by several studies. According to Smith et al. (1993), day length is the most important environmental factor acting on the appetite of the Atlantic salmon (Salmo salar). Feeding reduction for this species is directly related to the decrease in day length (Jørgensen and Jobling, 1992). Imsland et al. (1995) reported that the growth in turbot (Scophthalmus maximus) juveniles was faster when exposed to continuous light, though the fast growth obtained under these conditions had been kept only for a limited period of time.

*Author for correspondence 
Several studies have been conducted on the influence of photoperiod on fish (McCormick et al., 1987; Krakenes et al., 1991; Bromage, 1995; Cerqueira and Brügger, 2001). Most of those studies were carried out with saltwater fishes or freshwater fishes from the northern hemisphere. Although there are studies with Clarias gariepinus (Britz and Piennar, 1992; Appelbaum and McGeer, 1998), studies with Neotropical freshwater fish are still scarce. Therefore, the objective of this study was to evaluate the influence of photoperiod on the performance of Steindachneridion scriptum juveniles.

\section{MATERIALS AND METHODS}

Steindachneridion scriptum juveniles (60.2 \pm $16.0 \mathrm{~g} ; 176.8 \pm 13.2 \mathrm{~mm}$ ) were distributed in eighteen 150-L round tanks, eight juveniles per tank, keeping a similar biomass among the experimental units. Fish were exposed to photoperiods of 24L (light):0D (dark); 18L:6D; 14L:10D; 10L:14D; 6L:18D and 0L:24D for 90 days, each treatment with three repetitions. Fishes were fed twice a day, at 8:00 and 17:00h, under alternate light/dark conditions, except for the treatments with constant photoperiod. Pelleted feed 4-mm with $40 \%$ crude protein was offered in the proportion of $4 \%$ biomass/day, divided into equal parts at the two meals. In order to determine the fish feed consumption in the treatments, the difference between the number of pellets offered and the number of pellets collected in the tank after 30 minutes was assessed. During this period the fish behavior was observed, particularly for aggressiveness between them. The consumption, in grams, was obtained indirectly through the relationship between the number of pellets consumed and the mean number of pellets/gram. Feed conversion was calculated every fifteen days using the following formula: Feed conversion = weight of the dry food fed over the period/(Final weight - Initial weight).

The experiment was performed indoors, the each treatment in a separate space, divided by the pieces of black canvas. The illumination was provided by two fluorescent 40-watt light bulbs (630 lux), positioned $0.6 \mathrm{~m}$ above water surface. Thirty minutes prior to switching the lights on or off, an intermediate illumination system - consisting of a 15-watt yellow light bulb (21 lux) - was activated.
Preliminary observations have shown that the stress caused by a sudden change in light intensity could be reduced by a gradual change in light intensity.

Water flow in the tanks was $4 \mathrm{~L} / \mathrm{min}$ and continuous aeration was provided. Temperature and dissolved oxygen concentration were monitored twice a day (8:00 and 16:00h) with an YSI-55 oxygen meter. The $\mathrm{pH}$ and the concentrations of total ammonia and nitrite were verified every fortnight by the colorimetric method. $\mathrm{pH}$ was measured by titration, total ammonia by the methodology recommended by Koroleff (1976), and nitrite by Bendschneider and Robinson method (Golterman, 1978). Fortnightly, total weight and total length of all the fishes were measured for the growth evaluation. Length values were obtained by an ichthyometer and weight was measured using $0.01 \mathrm{~g}$ precision scales, after water excess was eliminated.

At the end of the study, data on total length, total weight, survival, biomass, feed consumption and feed conversion were interpreted by the analysis of variance (Zar, 1996) and, when necessary, followed by the Duncan Test, at a 0.05 significance level.

\section{RESULTS}

The variables of water quality did not show difference among the treatments. Mean values were $24.2 \pm 2.9^{\circ} \mathrm{C}$ and $27.8 \pm 4.2^{\circ} \mathrm{C}$, for morning and afternoon temperatures, respectively; $6.2 \pm 0.2$ for $\mathrm{pH}$, and $20 \mathrm{mg} / \mathrm{L} \mathrm{CaCO}_{3}$ for alkalinity. Dissolved oxygen concentration was above $3.5 \mathrm{mg} / \mathrm{L}$ throughout the experiment, with mean value of $7.21 \pm 0.92 \mathrm{mg} / \mathrm{L}$. The levels of total ammonia and nitrite were below 0.30 and $0.02 \mathrm{mg} / \mathrm{L}$, respectively.

During the study, $S$. scriptum juveniles exhibited resistance and rusticity in the experiment, with the death of only one fish from the treatment $6 \mathrm{~L}: 18 \mathrm{D}$ one week after the beginning of the experiment. Since the death had been caused by handling and not by the treatment itself, the individual was replaced by another one of similar size. There was no significant difference $(\mathrm{P}>0.05)$ among the treatments with regard to length throughout the 90 days of cultivation (Fig. 1). The same situation occurred for weight and biomass until the $75^{\text {th }}$ day. However, some differences were observed 
between treatments $0 \mathrm{~L}: 24 \mathrm{D}$ and $24 \mathrm{~L}: 0 \mathrm{D}$ on the $90^{\text {th }}$ day (Fig. 1).

On the first week of the experiment, some behavioral disorders were observed in the fishes submitted to long periods of light (18L and 24L) such as, aggression, dominance, and lack of appetite. These disorders became weaker as days passed and they were not observed anymore at the end of the first fortnight.

The mean feed consumption produced two distinct phases: one during the first 45 days, when the temperature was higher $\left(27.7 \pm 1.4^{\circ} \mathrm{C}\right)$ and statistical differences were not verified among the treatments $(\mathrm{P}>0.05)$; another one during the subsequent period, when the temperature decreased $\left(24.6 \pm 1.3^{\circ} \mathrm{C}\right)$ and the fishes presented lower feed consumption. Furthermore, feed consumption tended to reduce during shorter photoperiods: in the treatment with the shortest photoperiod (0L:24D), the reduction was more pronounced $(\mathrm{P}<0.05)$ than the one registered in the treatment with the longest photoperiod, on the $75^{\text {th }}$ day of culture (Fig. 2).

In the treatments with continuous light or permanent darkness, differences in feed consumption were not observed $(\mathrm{P}>0.05)$ at the feeding time, either in the morning or in the afternoon, throughout the experiment (Fig. 3). Nevertheless, some differences $(\mathrm{P}<0.05)$ were observed during the day in the first four fortnights of the experiment, when the consumption during the dark photoperiod represented $63.4 \%$ of the daily consumption. In the last two fortnights of the experiment, such difference decreased and it was not possible to find consumption differences $(\mathrm{P}>0.05)$ between the two feeding periods.

\section{DISCUSSION}

Most part of the literature regarding the influence of photoperiod on the fish metabolism is based on studies with Salmonidae species, whose performance is strongly affected by day length, and especially by the changes in the photoperiod. For most of these species, the reduction of day length reduces the growth (McCormick et al., 1987, Stefansson et al., 1989), which can be observed in both freshwater (Saunders et al., 1985; Stefansson et al., 1989; Solbakken et al., 1994) and saltwater salmon (Saunders and Harmon, 1988; Krakenes et al., 1991; Hansen et al., 1992).
Handling of photoperiod at different life stages has been successfully used in the growth, development and survival of other species, such as the gilthead sea bream, Sparus aurata (Tandler and Helps, 1985; Silva-Garcia, 1996), European sea bass, Dicentrarchus labrax (Barahona, 1979), and Lates calcarifer (Barlow et al., 1995).

Recent studies on the photoperiod have demonstrated that it can influence performance, survival, as well as the behavior of Brazilian freshwater fish during larviculture. Brycon orbignyanus showed positive relationship between longer photoperiods and survival during culture, with reduction in cannibalism (Reynalte-Tataje et al., 2002) whereas photoperiod influence on Salminus brasiliensis was related to the type feed used (Schütz and Nuñer, 2003). Rhamdia quelen juveniles, however, exhibited better performance when reared in the dark (Piaia et al., 1999). For Pseudoplatystoma corruscans, results indicated the occurrence of two distinct phases during larviculture, with better survival for the individuals reared in total darkness during the first five days, and after this period, continuous absence of the light was no longer necessary (Campagnolo, 2004). In the present study, S. scriptum juveniles presented differences in weight and biomass at the end of the 90 days of the experiment.

Nevertheless, no difference in length and survival was observed. A higher weight gain in the fish under continuous light (24L:0D), when compared to the ones kept in the dark, might be related to a continuous and intense metabolic activity, which was also observed by the higher feed consumption in the fishes exposed to a longer photoperiod. Fishes reared in alternate light and dark conditions showed preference to ingest food in the dark $(\mathrm{P}<0.05)$. However, fishes reared under continuous light or dark conditions did not present difference between feed consumption in the morning or in the afternoon. Reduction in the water temperature during the experimental period caused reduction in the feed intake in all the treatments, but it was more remarkable in the treatment of total darkness. 

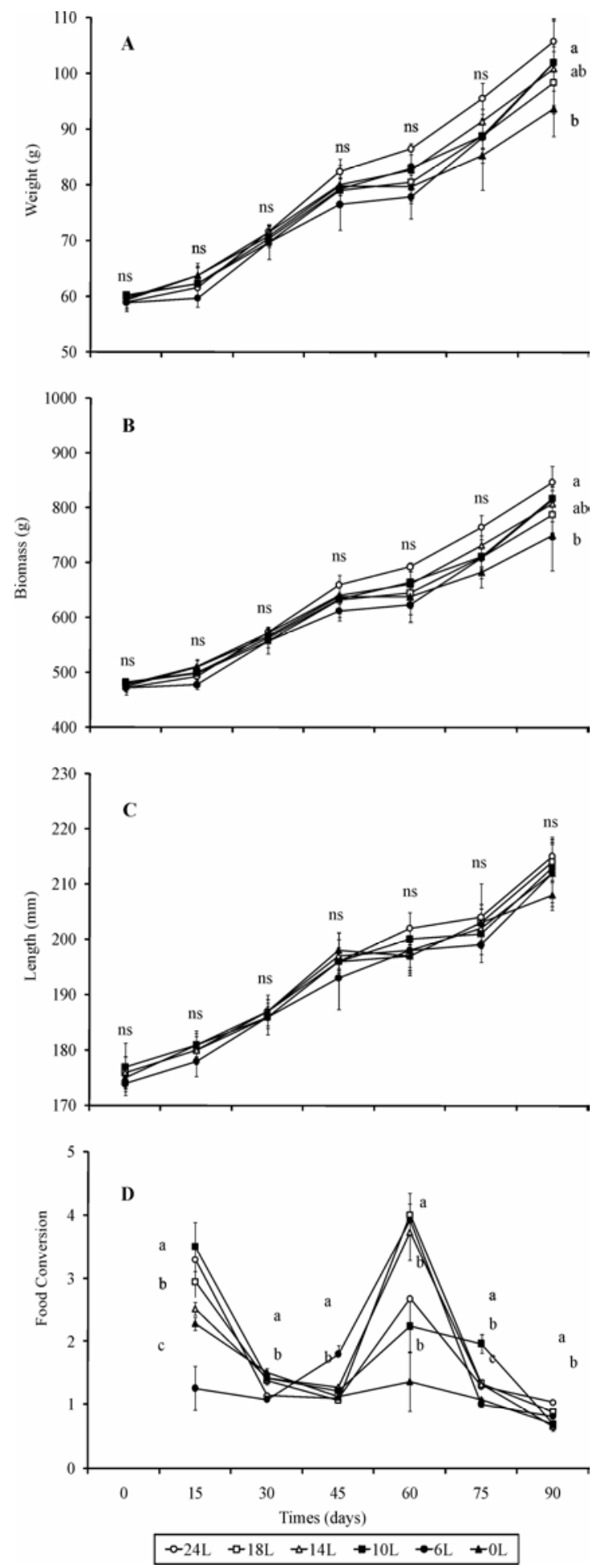

Figure 1 - Growth in weight (A) biomass (B) length (C) and food conversion (D) of Steindachneridion scriptum juveniles submitted to different photoperiods $[\mathrm{L}=$ light period (h)]. Different letters in the same day indicate significant differences by Duncan Test $(\mathrm{P}<0.05) . \mathrm{ns}=$ not significant 


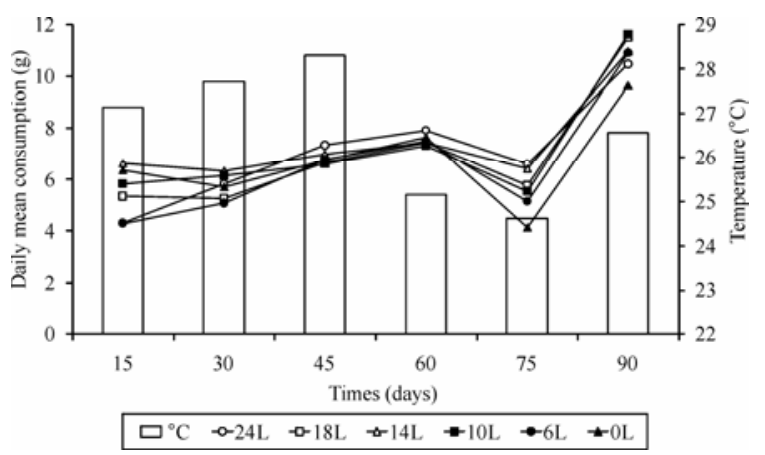

Figure 2 - Mean daily individual food consumption of Steindachneridion scriptum juveniles under different photoperiods for the 90 days of culture [ $\mathrm{L}=$ light period in hours]

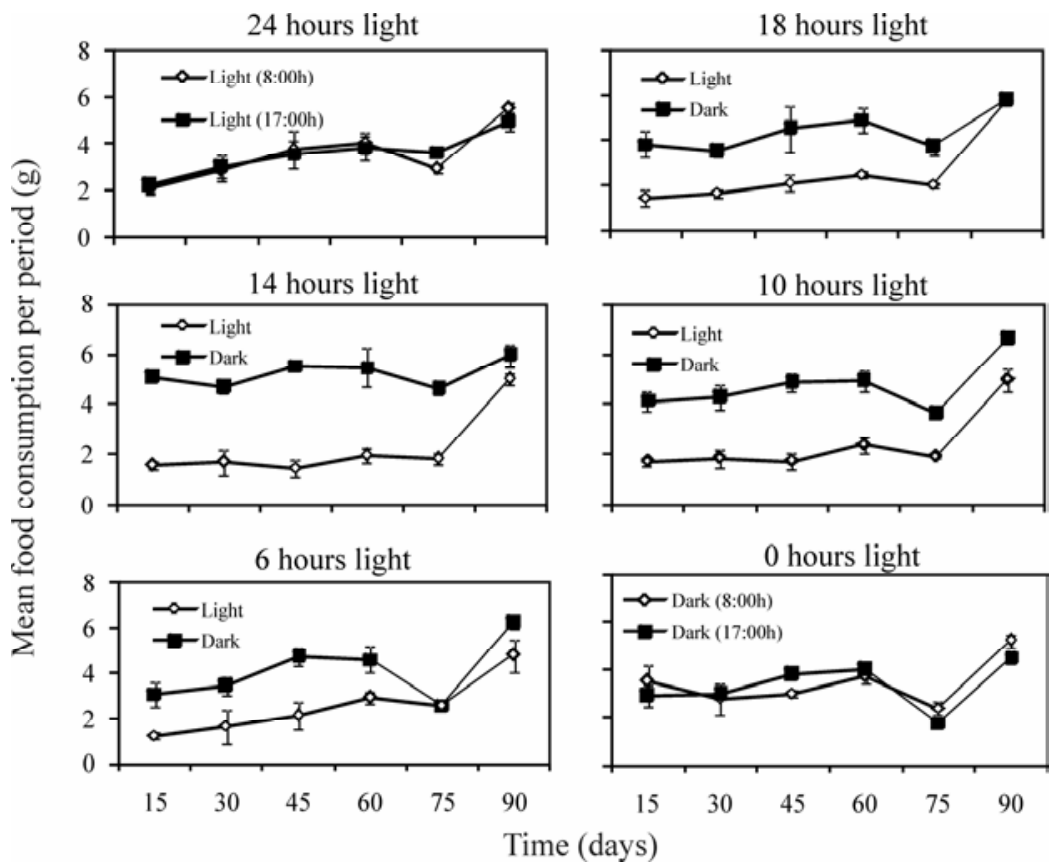

Figure 3 - Mean food consumption of Steindachneridion scriptum juveniles in two feeding periods $($ Dark $=8.00$ and Light $=17: 00 \mathrm{~h})$ under different photoperiods for 90 days

Studies carried out with other species demonstrated that the effect of photoperiod could be closely related to the temperature (Krakenes et al., 1991; Smith et al., 1993; Bouef and Yves-Le, 1999). Short photoperiods, associated with the low temperature can cause much stronger physiological responses than when the two variables act independently (Bouef and Yves-Le, 1999).
Throughout the experiment, S. scriptum showed an adaptation in feed consumption under light conditions, confirmed by a reduction in the difference between feed consumption in the light and in the dark.

Therefore, under the rearing conditions used in this experiment, it was observed that after the adaptation of $S$. scriptum to the light, the juveniles demonstrated higher growth during the 
photoperiod with continuous light than during the darkness. In the treatments of alternate light and dark, the highest feed consumption was registered in the dark period.

\section{RESUMO}

O objetivo do presente estudo foi avaliar a influência do fotoperíodo no cultivo de juvenis de suruvi Steindachneridion scriptum, nos seguintes fotoperíodos: 24L-0E (L=Luz; E= Escuro), 18L6E, 14L-10E, 10L-14E, 6L-18E e 0L-24E. Juvenis com comprimento e peso médio de $176,8 \pm 13,2 \mathrm{~mm}$ e $60,2 \pm 16,0 \mathrm{~g}$, respectivamente, foram distribuídos em 18 tanques de 150L, estocados na densidade de oito juvenis por tanques. Decorridos 90 dias de cultivo foram encontradas diferenças $(P<0,05)$ para as variáveis peso e biomassa, entre os tratamentos com iluminação contínua $(105,7 \pm 5,8 \mathrm{~g}$ e $845,9 \pm 46,0 \mathrm{~g})$ e com escuridão contínua $(93,3 \pm 4,9 \mathrm{~g}$ e $746,4 \pm 39,5 \mathrm{~g})$, respectivamente. Não foram observadas diferenças $(P>0,05)$ na sobrevivência $(100,0 \pm 0,0 \%)$ e no comprimento total $(212,5 \pm 2,5 \mathrm{~mm})$. Nas condições apresentadas os resultados nos permitem concluir que o suruvi, Steindachneridion scriptum, atingiu melhor peso e biomassa em cultivos que apresentam períodos com iluminação.

\section{REFERENCES}

Agostinho, A. A.; Junior, H. F. J.; Gomes, L. C.; Bini, L. M.; Agostinho, C. S. (1997), Composição, abundância e distribuição espaço-temporal da ictiofauna. In- A planície de inundação do alto rio Paraná: aspectos físicos, biológicos $e$ socioeconômicos. Eds. A. E. A. M. Vazzoler; A. A. Agostinho; N. S. Hahn. EDUEM, Maringá, pp. 179208.

Appelbaum, S. and McGeer, J. C. (1998), Effect of diet and light regime on growth and survival of African catfish (Clarias gariepinus) larvae and early juveniles. Aquac. Nutr., 4, 157-164.

Barahona, F. M. H. (1979), Some effects of light intensity and photoperiod on the sea bass larvae (Dicentrarchus labrax) reared at the Centre Océanologique de Bretagne. Aquaculture, 17, 311321.
Barlow, C. G.; Pearce, M. G.; Rodgers, L. J.; Clayton, P. (1995), Effects of photoperiod on growth survival and feeding periodicity of larval and juveniles barramundi Lates calcarifer (Bloch). Aquaculture, 138, 159-168.

Bouef, G. and Yves-Le Bail, P. (1999), Does light have an influence on fish growth? Aquaculture, 177, 129152.

Brett, J. R. (1979), Environmental factors and growth. In-Fish Physiology Bioenergetics and Growth. Eds. W. S. Hoar. Academic Press, New York, pp. 599677.

Britz, P. J. and Pienaar, A. G. (1992), Laboratory experiments on the effect of light and cover on the behaviour and growth of African catfish, Clarias gariepinus (Pisces, Clariidae). J. Zool., 227, 43-62.

Bromage, N. (1995), Broodstock management and seed quality-general considerations. In-Broodstock Management and Egg and Larval Quality. Eds. N. R. Bromage and R. J. Roberts. Blackwell, Oxford, pp. 124.

Campagnolo, R. (2004), Larvicultura do surubim, Pseudoplatystoma corruscans (Pisces, Pimelodidae), em diferentes densidades de estocagem e fotoperíodos. Master Thesis, Universidade Federal de Santa Catarina, Florianópolis, Brazil.

Carrillo, M.; Zanuy, S.; Prat, F.; Cerda, J.; Ramos, J.; Mañanos, E.; Bromage, N. (1995), Sea Bass (Dicentrarchus labrax L.). In-Broodstock Management and Egg and Larval Quality. Eds. N. R. Bromage and R. J. Roberts. Blackwell Scientific, Oxford, pp. 138-168.

Cerqueira, V. R. and Brügger, A. M. (2001), Effect of light intensity on initial survival of fat snook (Centropomus parallelus, Pisces: Centropomidae) larvae. Braz. Arch. Biol. Technol., 44, 343-349.

Golterman, H . L.; Clymo, R. S.; Ohnstad, M. A. M. (1978), Methods for chemical analysis of freshwater. Blackwell Scientific, Oxford.

Gwinner, E. (1986), Cirannual rhythms. Berlin, Springer Verlag.

Hansen, T.; Stefansson, S. O.; Taranger, G. L. (1992), Growth and sexual maturation in Atlantic salmon, Salmo salar L., reared in sea cages at two different light regimes. Aquacult. Fish. Manage, 23, 275-280.

Imsland, A. K.; Folkvord, A.; Stefansson, S.O. (1995), Growth, oxygen consumption and activity of juvenile turbot (Scophthalmus maximus L.) reared under different temperatures and photoperiods. Neth. J. Sea Res., 34, 149-159.

Jørgensen, E. H. and Jobling, M. F. (1992), Feeding behaviour and effects of feeding regime on growth of Atlantic salmon, Salmo salar. Aquaculture, 101, 135146.

Koroleff, F. (1976), Determination of nutrients. InMethods of sea water analysis. Ed. K. Grasshoff. Verlag Chemie, Weinhein, 117-181. 
Krakenes, R.; Hansen, T.; Stefansson, S. O.; Taranger, G. L. (1991), Continuous light increases growth rate of Atlantic salmon (Salmo salar L.) postsmolts in sea cages. Aquaculture, 95, 281-287.

McCormick, S. D.; Saunders, R. L.; Henderson, E. B.; Harmon, P. R. (1987), Photoperiod control of parrsmolt transformation in Atlantic salmon (Salmo salar L.): changes in salinity tolerance, gill $\mathrm{Na}^{+}, \mathrm{K}^{+}-$ ATPase activity, and plasma thyroid hormones. Can. J. Fish. Aquatic. Sci., 44, 1462-1468.

Piaia, R.; Baldisserotto, B.; Townsend, C. (1999), Growth and survival of fingerlings of silver catfish exposed to different photoperiods. Aquacult. Int., 7, 201-205.

Reynalte-Tataje, D.; Luz, R. K.; Meurer, S.; ZaniboniFilho, E.; Nuñer, A. P. O. (2002), Influência do fotoperíodo no crescimento e sobrevivência de póslarvas de piracanjuba Brycon orbignyanus (Valenciennes, 1849) (Osteichthyes, Characidae). Acta Scient., 24, 439-443.

Saunders, R. L.; Henderson, E. B.; Harmon, P. R. (1985), Effects of photoperiod on juvenile growth and smolting of Atlantic salmon and subsequent survival and growth in sea cages. Aquaculture, 45, 55-66.

Saunders, R. L. and Harmon, P. R. (1988), Extended day length increases postsmolt growth of Atlantic salmon. World Aquac., 19, 72-73.

Schütz, J. H.; Nuñer, A. P. O. (2007), Growth and survival of dorado Salminus brasiliensis (Pisces, Characidae) post-larvae cultivated with different types of food and photoperiods. Braz. Arch. Biol. Technol., 50, 435-444.

Silva-Garcia, A. J. (1996), Growth of juvenile gilthead seabream (Sparus aurata L.) reared under different photoperiod regimes. Isr. J. Aquac., 48, 84-93.
Smith, I. P.; Metcalfe, N. B.; Huntingford, F. A.; Kadri, S. (1993), Daily and seasonal patterns in the feeding behaviour of Atlantic salmon (Salmo salar L.) in a sea cage. Aquaculture, 117, 165-178.

Solbakken V. A.; Hansen T.; Stefanson S. O. (1994), Effects of photoperiod and temperature on growth and parr-smolt transformation in Atlantic salmon (Salmo salar L.) and subsequent performance in seawater. Aquaculture, 121, 13-27.

Stefansson, S. O.; Naevdal, G.; Hansen, T. (1989), The influence of three unchanging photoperiods on growth and parr-smolt transformation in Atlantic salmon, Salmo salar L. J. Fish Biol., 35, 237-247.

Tandler, A. and Helps, S. (1985), The effects of photoperiod and water exchange rate on growth and survival of gilthead sea bream (Sparus aurata, Linnaeus; Sparidae) from hatching to metamorphosis in mass rearing systems. Aquaculture, 48, 71-82.

Zaniboni-Filho, E. and Schulz, U.H. (2003), Migratory fishes of the Uruguay river. In-Migratory fishes of the South America: biology, social importance and conservation status. Eds. J. Carolsfeld; B. Harvey; A. Baer; C. Ross. IDRC/World Bank/World Fisheries Trust, Ottawa, pp. 135-168.

Zar, J. H. (1996), Biostatistical analysis. Prentice Hall, New Jersey.

Zohar, Y.; Harel, M.; Hassin, S.; Tandler, A. (1995), Gilt-head sea bream (Sparus aurata). In-Broodstock Management and Egg and Larval Quality. Eds. N. R. Bromage and R. J. Roberts. Blackwell Scientific, Oxford, pp. 94-117.
Received: July 15, 2005; Revised: November 29, 2006; Accepted: April 10, 2008 

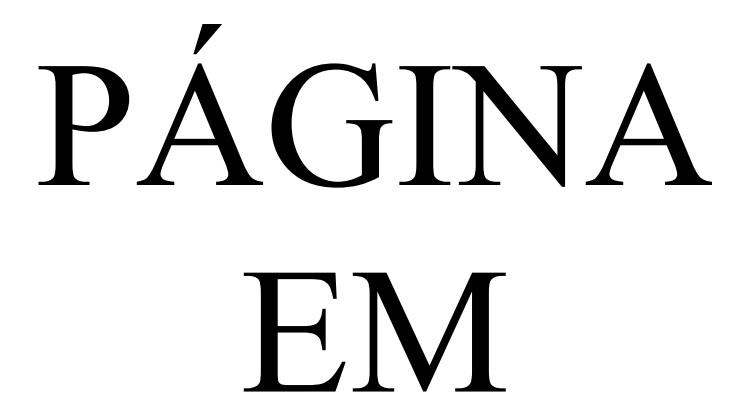

BRANCO 